\title{
Getting Back on Track: Macroeconomic Policy Lessons from the Financial Crisis
}

John B. Taylor

\begin{abstract}
This article reviews the role of monetary and fiscal policy in the financial crisis and draws lessons for future macroeconomic policy. It shows that policy deviated from what had worked well in the previous two decades by becoming more interventionist, less rules-based, and less predictable. The policy implications are thus that policy should "get back on track." The article is a modified version of a presentation given at the Federal Reserve Bank of Philadelphia's policy forum "Policy Lessons from the Economic and Financial Crisis," December 4, 2009. The presentation was made during a panel discussion that also included James Bullard and N. Gregory Mankiw.
\end{abstract}

Federal Reserve Bank of St. Louis Review, May/June 2010, 92(3), pp. 165-76.

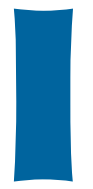

started doing research on the financial crisis in the spring and summer of 2007 just before the crisis flared up in August of that year. From the start, my approach has been empirical. I have not focused on who said what to whom when, however interesting and ultimately important that story is. Rather I looked at the timing of events and at data-at interest rates, stock prices, credit flows, money supply, housing starts, income, consumptionusing statistical techniques and simple charts, concentrating on what is amenable to economic analysis. I also tried to use the discipline of "counterfactuals," or stating what alternative policies or events would have been and using economic models to examine the impacts. I looked at economic policy throughout the crisis, including the period leading up to the panic in the fall of 2008 and the year and a half since then. What I have found since the start of this research is that government interventions-many wellintentioned government interventions- did a great deal of harm. With these findings in mind, I wrote one of the first books on the crisis; it was based on a November 2008 speech in honor of David Dodge, the former governor of the Bank of Canada. I called the book Getting Off Track: How Government Actions and Interventions Caused, Prolonged, and Worsened the Financial Crisis. I think that events since that book was published have reinforced the title.

In these remarks I want to consider the macroeconomic-monetary and fiscal, as distinct from regulatory-policy implications of these findings. As I hope to show, once the findings are clearly laid out, the macroeconomic policy implications jump out at you and happen to be quite straightforward: Get back on track. Return to what was working well before policy got off track.

\section{FROM THE GREAT MODERATION TO THE GREAT DEVIATION TO THE GREAT RECESSION}

Figure 1 provides an illustration of what I have in mind. It shows the growth rate of real GDP in the United States, quarter by quarter, back to

John B. Taylor is the Mary and Robert Raymond Professor of Economics at Stanford University and the George P. Shultz Senior Fellow in Economics at the Hoover Institution.

(C) 2010, The Federal Reserve Bank of St. Louis. The views expressed in this article are those of the author(s) and do not necessarily reflect the views of the Federal Reserve System, the Board of Governors, or the regional Federal Reserve Banks. Articles may be reprinted, reproduced, published, distributed, displayed, and transmitted in their entirety if copyright notice, author name(s), and full citation are included. Abstracts, synopses, and other derivative works may be made only with prior written permission of the Federal Reserve Bank of St. Louis. 


\section{Figure 1}

\section{From Great Moderation to Great Deviation to Great Recession}

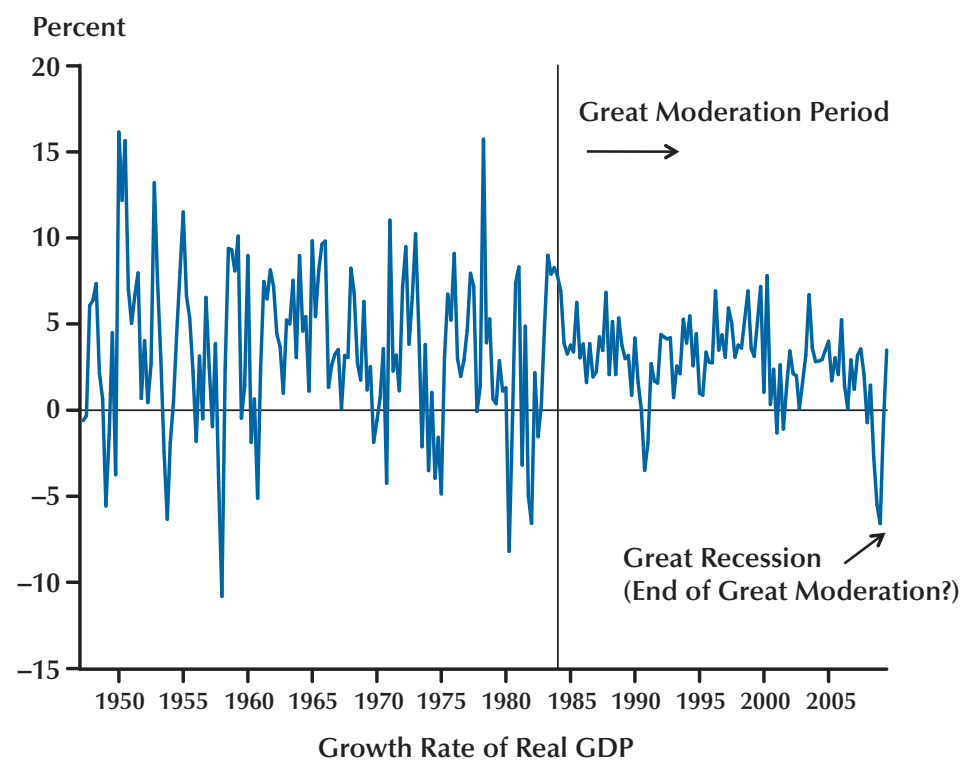

the late 1940s. The high volatility during the earlier decades-the 1950s through the 1970s-is clearly visible. During the latter part of this highvolatility period, I was a visiting scholar at the Federal Reserve Bank of Philadelphia; we were studying monetary policy decisions, trying to understand the reasons for the volatility and to find ways to reduce it. ${ }^{1}$ As Figure 1 shows, the high volatility ended in the early 1980s. It is hard to say exactly when. Some economists say 1984. I say a little earlier, at the beginning of the expansion in 1982. However you date it, a Great Moderation-two or more decades of much less volatility-followed. And this Great Moderation, with its long expansions and short recessions and low inflation, continued until the recent financial crisis, when it apparently ended.

\footnotetext{
1 As a visiting scholar at the Federal Reserve Bank of Philadelphia in the late 1970s, I had the opportunity to participate in briefings for the president of the Bank before FOMC meetings. We discussed how policy should become more aggressive with respect to policy rate increases and how more attention should be paid to real interest rates. It is amazing how much things changed after that, but I worry that perhaps history is repeating itself.
}

Why did the Great Moderation end? In my view, the answer is simple. The Great Moderation ended because of a "Great Deviation," in which economic policy deviated from what was working well during the Great Moderation. Compared with the Great Moderation, policy became more interventionist, less rules-based, and less predictable. When policy deviated from what was working well, economic performance deteriorated. And lo and behold, we had the Great Recession.

\section{Monetary Excesses}

A good illustration of policy decisions that fall under this Great Deviation rubric is shown in Figure 2. This chart, which appeared in The Economist magazine, October 18, 2007, plots the interest rate set by the Federal Reserve from 2000 to early 2007. I reproduced this chart in Getting Off Track; a version first appeared in the paper I prepared for the Kansas City Fed Symposium in the summer of 2007. Note how the interest rate came down in the recession of 2001, as it would be expected to do, but then became very lowfalling below 2 percent and then down to 1 per- 


\section{Figure 2}

\section{Federal Funds Rate, Actual and Counterfactual}

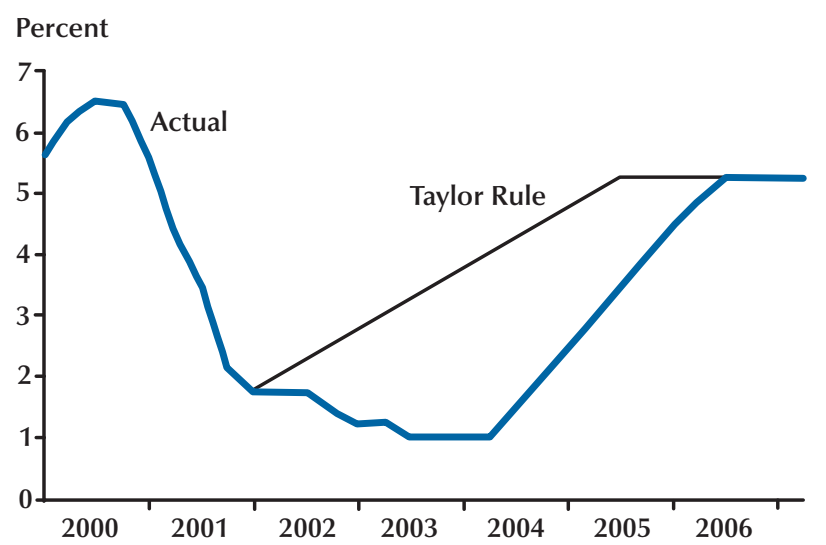

NOTE: From Taylor (2007).

cent-before rising back up again slowly. This is the period in which interest rates were too low according to the Taylor rule, ${ }^{2}$ which is shown by the dark line in the figure representing what policy would have been had it followed the principles that worked well for the previous 20 years. That is, interest rates would not have reached such a low level and they would have returned much sooner to the neutral level. So in this sense there was a deviation from a more rules-based policy. The deviation was larger than in any period since the unstable decade before the Great Moderation. ${ }^{3}$ One does not need to rely on the Taylor rule to come to the conclusion that rates were held too low. The real interest rate was negative for a very long period, similar to what happened in the 1970s.

So it should not be surprising that such an unusual policy led to some problems. According to my research, the low interest rates added fuel to the housing boom, which in turn led to risk taking in housing finance and eventually a sharp

2 I sometimes wish it were not called the Taylor rule, because I lose objectivity discussing it.

3 Ben Bernanke (2010) replied to this criticism and I responded in Taylor (2010a). increase in foreclosures and balance sheet deterioration at many financial institutions. To test the connection with the housing boom, I built a simple model relating the federal funds rate to housing construction. I showed that a counterfactual higher federal funds rate would have avoided much of the boom as described in my 2007 Jackson Hole paper. ${ }^{4}$

I call this monetary policy decision a discretionary intervention by government because it was an intentional departure from the policies that were followed in the decades before. Some policymakers say the departure was undertaken to avoid downside risk, perhaps a Japanese-style deflation. I have no doubt that it was well-intentioned, an example of what used to be called discretionary fine tuning. The Fed's descriptions that rates would be low for a "prolonged period" and that rates would rise at a "measured pace" illustrate this fine tuning. Markets were generally aware of it and the departure from policy rules confirmed it. I think it is an example where the perfect can

4 Alan Greenspan replied to this criticism (see Greenspan, 2010, for example) focusing on the long rate, not the short rate. My response is found in a "frequently asked questions" section of Getting Off Track. 
Figure 3

\section{The Term Auction Facility and the LIBOR-OIS Spread}

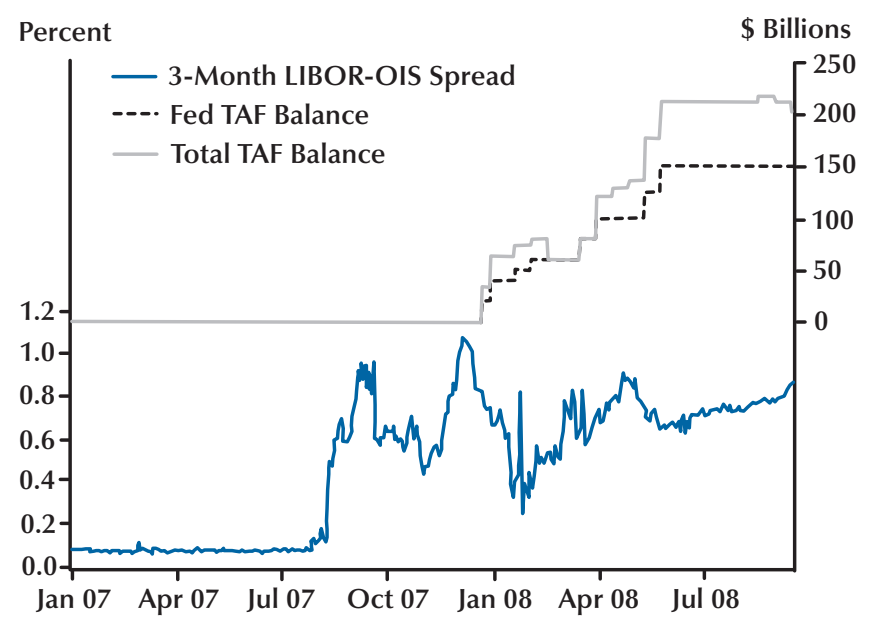

become the enemy of the good. As Milton Friedman ${ }^{5}$ once put it, "The attempt to do more than we can will itself be a disturbance that may increase rather than reduce instability."

This is not the whole government part of the story, of course. The government-sponsored enterprises, Fannie Mae and Freddie Mac, also encouraged the housing boom. But whether or not you include these on the list, the ultimate source of the extraordinary housing boom and the subsequent housing bust and financial distress was government policy. Capital inflows from abroad may have added to the problem, but the evidence is clear that monetary policy had deviated in the direction that would likely lead to poor policy performance. This is in contrast to the policy decisions during the Great Moderation. ${ }^{6}$

\section{More Interventions}

When the crisis became evident with the flareup in the money markets in August 2007, a host

5 Testimony to the Joint Economic Committee in 1958, quoted in Friedman and Heller (1969, p. 48).

6 Many papers were written before this crisis on the effects of monetary policy in the Great Moderation: e.g., Ben Bernanke (2004) showed that policy rules made a substantial difference in, and were largely responsible for, the Great Moderation. of additional interventions were undertaken by government, but these had little positive impact. In my view the crisis was misdiagnosed as a liquidity problem rather than a counterparty risk problem in the banks; as a result, the policies did not address the problem. To illustrate this perspective, consider Figure 3, which shows the LIBOR-OIS spread through the summer of 2008 along with one of these interventions-the term auction facility (TAF). The LIBOR-OIS spread is the difference between the interest rate on 3-month unsecured loans between banks (LIBOR) and an estimate of what the federal funds rate will be, on average, over those same three months (OIS). The spread is a good measure of tension in the interbank market. The jump in the LIBOR-OIS spread in August 2007 is very clear in Figure 3. I first began researching that jump soon after it occurred, trying to determine what caused it. I enjoy following the federal funds market, and when I saw this jump I was naturally curious. Based on work with John Williams of the Federal Reserve Bank of San Francisco (Taylor and Williams, 2009), I concluded the jump in spreads was due to counterparty risk in the banking sector. We now know the banks were holding many toxic assets, but that was not clear to many at the time, and the problem was diagnosed as a liquidity 


\section{Figure 4}

\section{Consumption and the Jump in Personal Disposable Income Due to the Fiscal Stimulus: Part 1 (Monthly Data, Seasonally Adjusted, Annual Rates)}

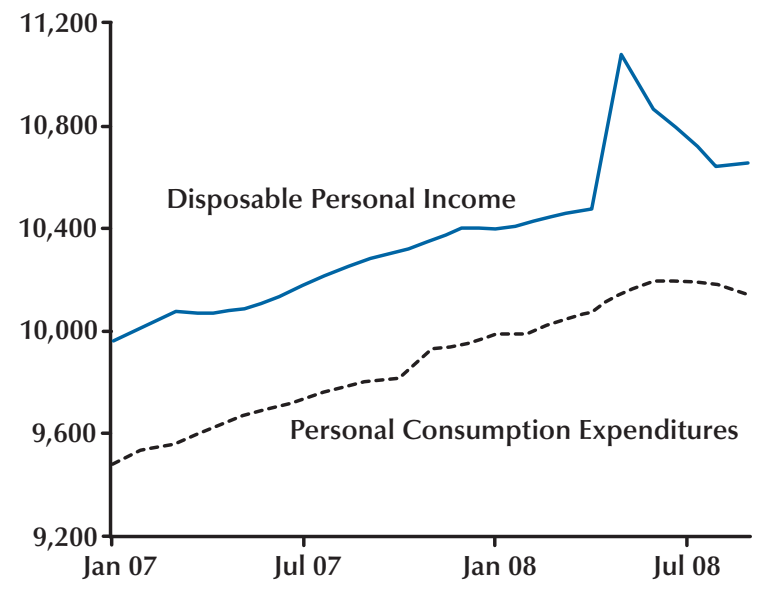

problem. John Williams and I called our paper "A Black Swan in the Money Market” because the event was so unusual.

As a result of the misdiagnosis, one of the policy interventions was to increase the supply of liquidity through the TAF, as shown in Figure 3, with some foreign central banks joining in. When these facilities were first enacted, in late December 2007, the LIBOR-OIS spread declined a bit. But this respite did not last, and as is clear in Figure 3 the spread rose again and remained high. I find no strong evidence that these liquidity facilities affected these rates. And the evidence remains lacking to the present. In fact, if you look at reasonable measures of risk in the banking sector, such as the spread between secured and unsecured interbank loans, you can explain the movements in LIBOR-OIS very well. In my view, this policy intervention prolonged the crisis because it did not address the balance sheet problem at the banks and other financial institutions.

\section{Discretionary Countercyclical Fiscal Actions}

Policy interventions also occurred on the fiscal side. Figure 4 illustrates one discretionary fiscal intervention-the fiscal stimulus of 2008. The chart shows that disposable personal income rose as checks were sent to people as part of the stimulus package. The intention was to provide temporary tax rebates so the recipients would spend that money and jump-start the economy. This action also was a deviation from policies that were working well for 20 years, a period when very few such discretionary policies were implemented.

Figure 3 provides no evidence that the stimulus has had any impact in raising consumption. While disposable income increased dramatically as a result of the rebates, personal consumption expenditures did not increase. This is what economic theory - the permanent income theory or life cycle theory of consumption-would tell you. Again, the intervention did not address the toxic asset problem, and the crisis continued.

\section{Interventions to Rescue the Creditors of Individual Financial Firms}

The most unusual and significant actions were the government interventions to rescue financial firms and their creditors, culminating in the rollout of the Troubled Asset Relief Program 


\section{Figure 5}

\section{Event Study of the Worsening Crisis: LIBOR-OIS Spread, Fall 2008}

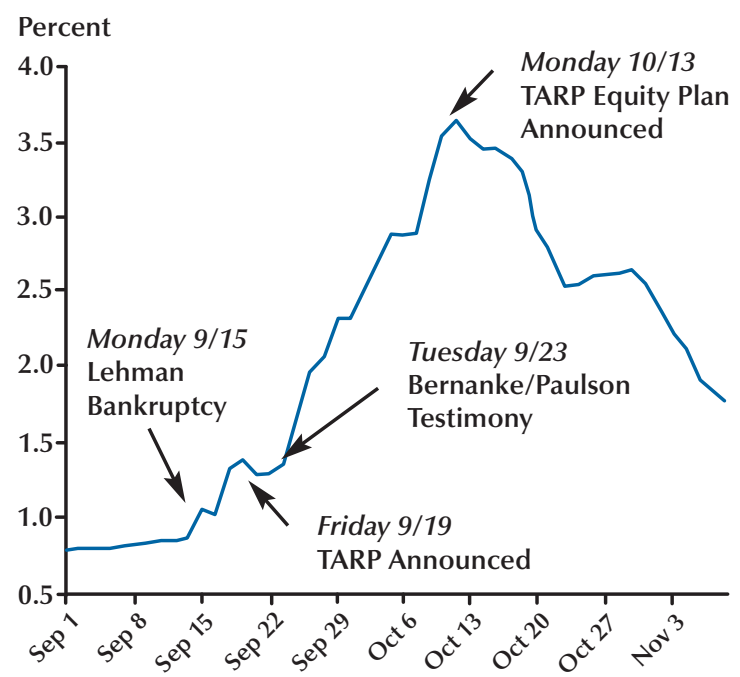

(TARP) during the week of September 21, 2008. In my view, however, the rollout was part of a chaotic series of interventions going back to Bear Stearns in March 2008 and included the Fannie and Freddie interventions, the AIG intervention, and even the Lehman non-intervention, which I include because the decision not to intervene was a big surprise. Figure 5 shows the LIBOR-OIS spread during the panic period. Recall from Figure 4 that the LIBOR-OIS spread jumped in August 2007. But the spread increased by much more during the panic, by more than 350 basis points after hovering close to 100 basis points since August 2007. Figure 5 focuses on several key events, which are labeled on the graph. The Lehman bankruptcy occurred early Monday, September 15, after a long weekend during which a decision was made not to bail out Lehman and its creditors. Observe that the LIBOR-OIS spread increased slightly on September 15 and then fluctuated during the rest of the week. But these turned out to be relatively minor movements. The major movements in the spread occurred with the government's rollout of the TARP and the skeptical reaction in the Congress and much of the country to that TARP proposal. Note that Federal Reserve
Board Chairman Bernanke and Secretary of the Treasury Hank Paulson gave testimony on Tuesday, September 23, to the Senate Banking Committee. The market turmoil significantly worsened in the following weeks. In the rollout of the TARP, people were warned by the government not only that "there is systemic risk" but also that "the Great Depression is coming." This scared people around the world and led to panic and a severe hit to the world economy.

Could it have been different? Could at least the chaotic pattern of these interventions been avoided? We can debate whether the intervention in the case of Bear Stearns was appropriate or not. I have my doubts, but let's put those doubts aside. The key question then pertains to the period after that intervention. It is not too difficult to imagine an environment in which the markets and the public in general would have been guided by a description by the Federal Reserve and the U.S. Treasury of the reasons behind the Bear Stearns intervention, as well as the direction and intentions of policy going forward. This sort of transparency would have given people some sense of policy actions to come. But no such description was provided. 


\section{Figure 6}

\section{Event Study of the Worsening Crisis: S\&P 500 Index, Fall 2008}

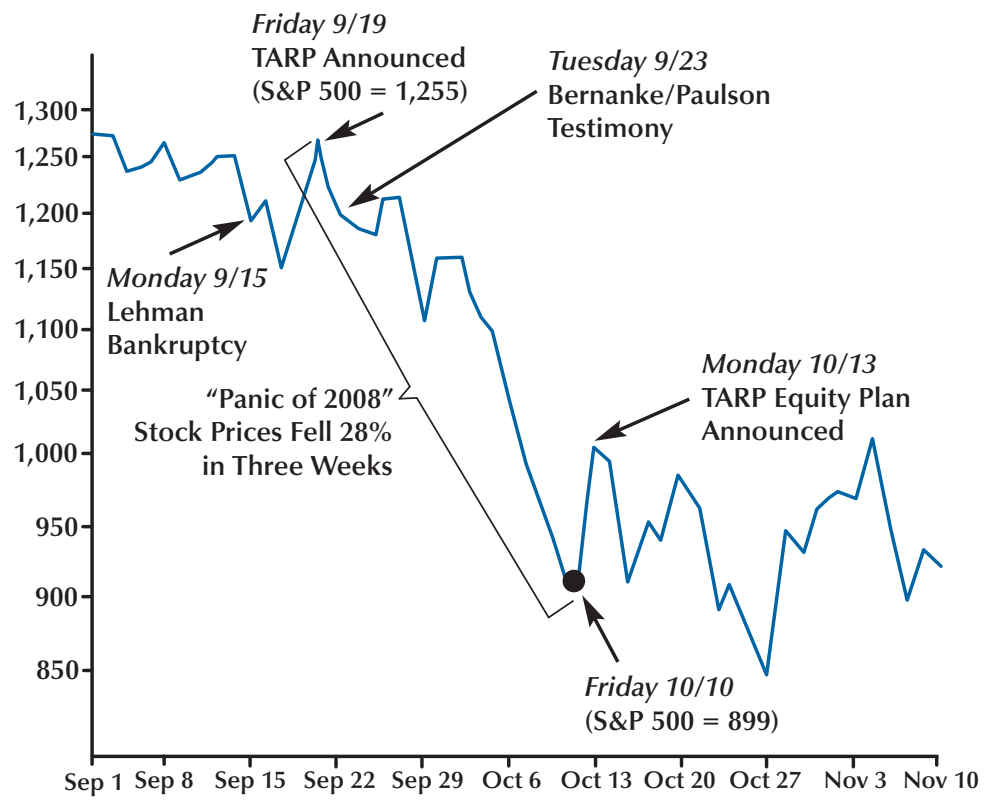

\section{Table 1}

\section{Major Stock Price Indices During Fall 2008}

\begin{tabular}{lrrrrrr} 
& S\&P & FTSE & DAX & CAC & IBOVESPA & NIKKEI \\
\hline September 12 & 1,252 & 5,417 & 6,235 & 4,332 & 52,393 & 12,215 \\
September 15 & 1,192 & 5,204 & 6,064 & 4,169 & 48,419 & 11,609 \\
September 19 & 1,255 & 5,311 & 6,134 & 4,324 & 53,055 & 11,921 \\
October 10 & 899 & 3,821 & 4,544 & 3,176 & 40,829 & 8,276
\end{tabular}

NOTE: CAC, French stock market index (Cotation Assistée en Continu); DAX, German stock market index (Deutscher Aktien Index); FTSE, British stock market index (Financial Times Stock Exchange); IBOVESPA, Brazilian stock market index (Brazilian Índice Bovespa: Brazilian Bolsa de Valores do Estado de São Paulo [São Paulo Stock, Mercantile \& Futures Exchange]); NIKKEl, stock market index for Tokyo Stock Exchange; S\&P, Standard \& Poor's U.S. stock index.

Figure 5 reveals something else that bolsters the case that uncertainty about the interventions made things worse. The turning point in the panic-measured by the LIBOR-OIS-occurred when uncertainty about the TARP was removed. Recall that the testimony on September 23, 2008, stated that the original purpose of the TARP was to buy up toxic assets on banks' balance sheets.
People were skeptical about how that would work and government officials had difficulty explaining how it would work. Consequently, there was much uncertainty at the outset. The program itself was apparently not prepared very much in advance. But, after the TARP was changed and it was made clear on late Sunday, early Monday, October 13, 2008, that the funds would be used 


\section{Figure 7}

\section{Consumption and the Jump in Personal Disposable Income Due to the Fiscal Stimulus: Part 2 (Monthly Data, Seasonally Adjusted, Annual Rates)}

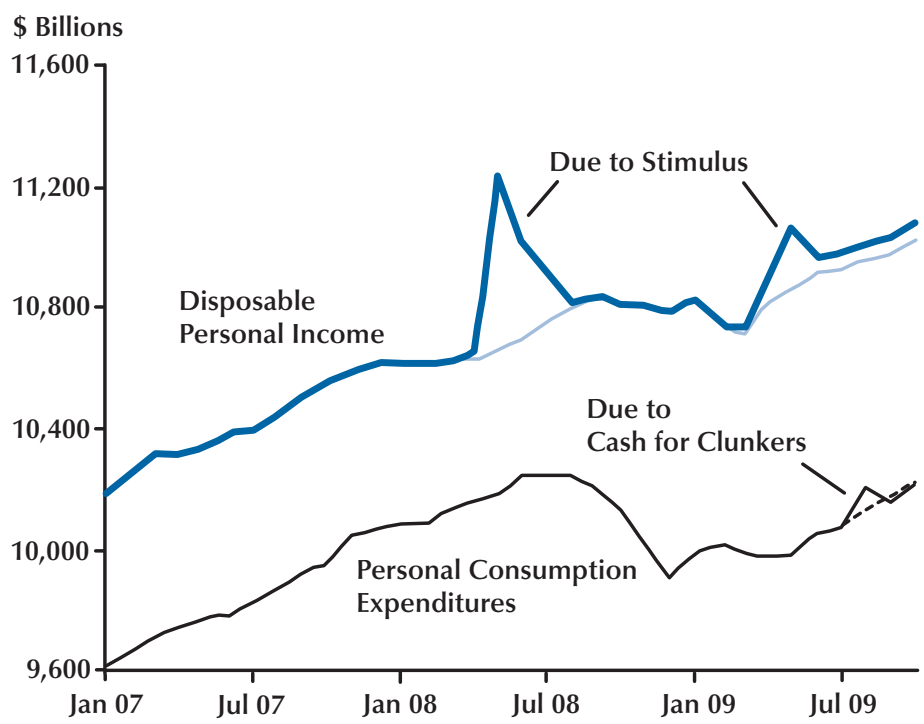

to inject equity rather than buy toxic assets, conditions began to improve. You can see that this was the peak for the LIBOR-OIS spread, which continued to come down further.

Other market measures show similar patterns. Figure 6 is the same type of event study as Figure 5 except it uses the S\&P 500. Observe that the S\&P 500 was higher the Friday after the Lehman bankruptcy than it was the Friday before. You can't prove causation with this timing of events, but it certainly suggests that the Lehman bankruptcy alone was not the cause of the panic. The sharp drop in the S\&P 500 occurred much later. Moreover, the end of the panic in the stock market is on October 13, when the TARP equity plan was announced.

This panic quickly spread beyond the United States, as international data show. Table 1 shows major stock market indices around the world. The pattern is very similar to the United States. Equity prices came down on Monday, September 15, 2008, but were higher on Friday, September 19, after which they collapsed by 30 percent or so. Britain's FTSE behaves roughly this way and the story is the same for the German, French, and Japanese stock markets. It was a common story around the world. According to these data, the disruption does not seem to be as much due to the Lehman Brothers bankruptcy as it is to the series of policy responses.

What about other policy actions during the panic from late September into October? The panic is a complex period to analyze because many actions were taken at the same time, including the Fed's programs to assist money market mutual funds and the commercial paper market. These were intertwined with the FDIC bank debt guarantees and the clarification on October 13, after weeks of uncertainty, that the TARP would be used for equity injections. As discussed above, this clarification was a major reason for the halt in the panic in my view. Nevertheless, on the basis of conversations with traders and other market participants, the Fed's actions taken during the panic were also helpful in rebuilding confidence in money market mutual funds and the commercial paper market. 


\section{Figure 8}

\section{Federal Debt as a Percentage of GDP}

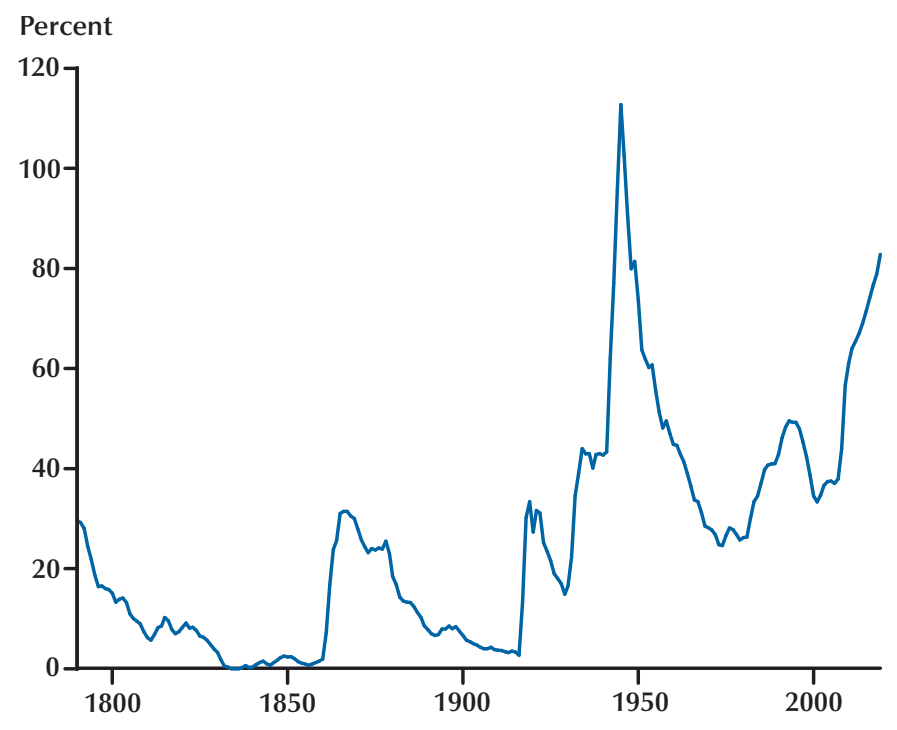

\section{Interventions After the Panic}

Two other interventions were introduced by the Fed in the period following the panic: the program to purchase mortgage-backed securities (MBS) and the Term Asset-Backed Securities Loan Facility (TALF). The MBS program has turned out to be much larger, amounting to $\$ 1.25$ trillion.

My assessment of that program, based on research with Johannes Stroebel at Stanford, is that it had a rather small effect on mortgage rates once one controls for prepayment risk and default risk, but the estimates are uncertain. The TALF was very slow to start and it is still quite small.

On the fiscal side, interventions also continued. Figure 7 focuses on the impact of the second discretionary countercyclical stimulus package, which was passed in February 2009. Observe that the depiction here is simply an extension of Figure 4. Compared with the 2008 stimulus, the 2009 stimulus was larger, but the amount paid in checks was smaller and more drawn out. Nevertheless, there is still no noticeable effect on consumption. I also show the timing of the "Cash for Clunkers" program in Figure 7; it did encourage some consumption, but did not last and cannot be considered an effective method to stimulate the economy. In addition, my analysis of the government spending part of the stimulus is that it too had little positive impact.

\section{The Legacy of the Interventions}

Regardless of whether one thinks these interventions were bad or good, they have helped create huge legacies of debt, monetary overhang, and questionable policy precedents. First consider the deficit and the debt. To be sure, it is not only the crisis that has caused debt problems for the United States. Other powerful forces had been at work for some time. But the crisis has distracted us from efforts to deal with those forces.

Figure 8 shows the federal debt as a share of GDP, going back to the beginning of the United States of America. You can see the huge increase in the ratio during World War II, which fortunately was reversed in the years after the war. But we are heading up in that direction again. The CBO's projection through the next eight years shows a similarly huge increase in federal debt. This increase is partly due to the stimulus, partly due to the recession, and, more importantly now, 
Figure 9

Federal Debt as a Percentage of GDP

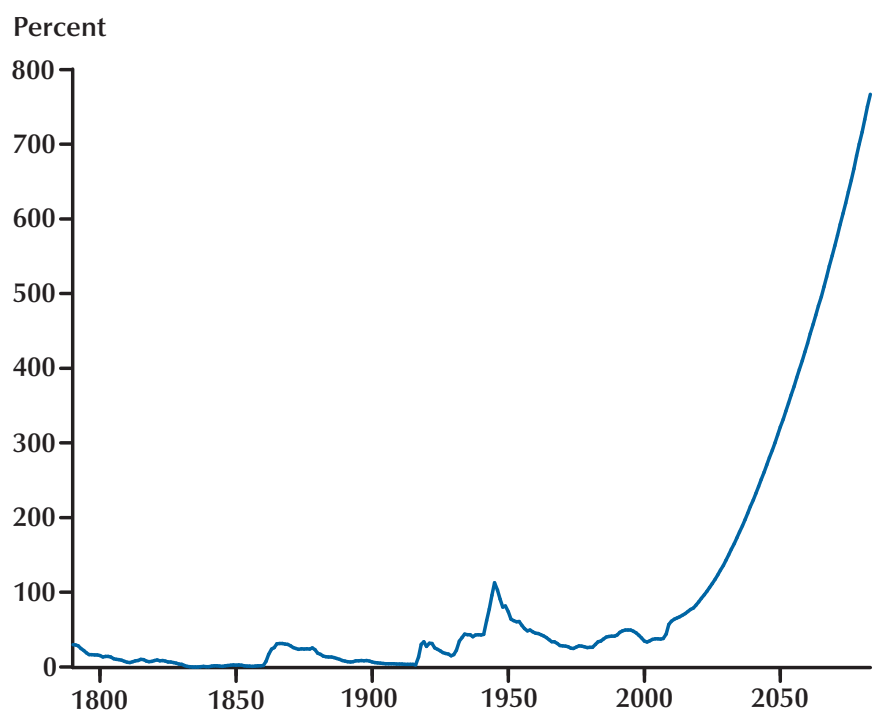

Figure 10

\section{Reserve Balances of Depository Institutions at Federal Reserve Banks}

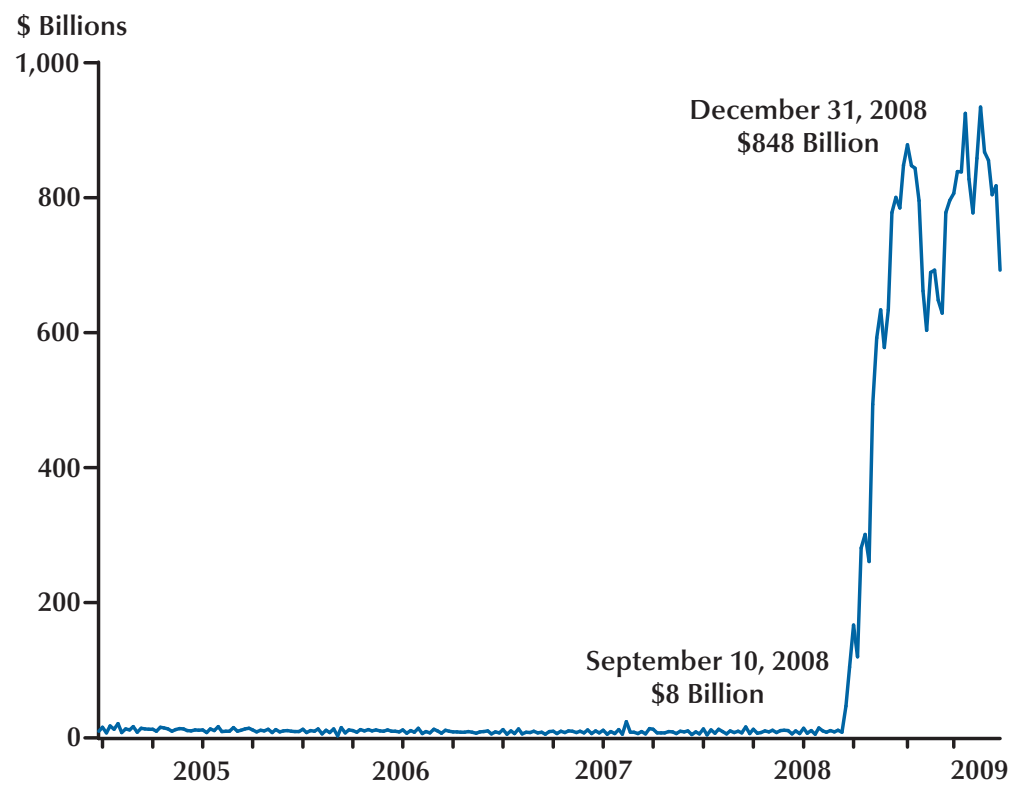


partly due to the inability to rein in spending for our entitlement programs.

Figure 9 extends the data shown in Figure 8 for the next few decades. According to the CBO, the debt reaches 700 percent of GDP. This huge percentage dwarfs the debt the United States incurred after World War II. Of course, we all hope this is not going to happen; the United States of America would not be the United States of America if that were to happen. So something has got to give, and the question is what.

Whether one believes that the monetary policy actions worked or not, their consequences going forward are also negative. First, they raise questions about Fed independence. The programs are not monetary policy as conventionally defined, but rather fiscal policy or credit allocation policy financed through money creation and not by taxes or public borrowing. Why should such policies be run by an independent agency of government?

Second, unwinding the programs creates uncertainty. To wind down the programs in the current situation, the Fed must reduce the size of its MBS portfolio and reduce reserve balances. Figure 10 shows the huge size of reserve balances. The reserves rose because of the need to finance the Fed's interventions. Because there is uncertainty about how much impact the purchases have had on mortgage interest rates, there is uncertainty about how much mortgage interest rates will rise as the MBS are sold. There is also uncertainty about why banks are holding so many excess reserves. If the current level of reserves represents the amount banks desire to hold, then reducing reserves could cause a further reduction in bank lending.

Third, there is the risk of inflation. If the Fed is not able to reduce the size of the balance sheet as the economy recovers and as public debt increases, then inflationary pressures will undoubtedly increase.

\section{POLICY IMPLICATIONS}

In sum, this brief review of my research on the crisis shows that the government interventions taken before, during, and after the crisis did more harm than good. These interventions were a deviation from what was working well. We got off track.
The policy implications are thus clear: Macroeconomic policy should get back on track.

For fiscal policy, this means avoiding further debt-increasing and wasteful discretionary stimulus packages, which do little to stimulate GDP. Ten years ago there was a near consensus that such programs were ineffective. Fiscal policy should focus on reducing the deficit and the growth of the debt-to-GDP ratio. Reforming existing entitlement programs to hold their growth down and limiting the creation of additional entitlement programs are essential.

For monetary policy, it means, as I testified at the House Financial Services Committee in March (Taylor, 2010b), returning to a policy with four basic characteristics: "First, the short-term interest rate (the federal funds rate) is determined by the forces of supply and demand in the money market. Second, the Fed adjusts the supply of money or reserves to bring about a desired target for the short-term interest rate; there is thus a link between the quantity of money or reserves and the interest rate. Third, the Fed adjusts the interest rate depending on economic conditions: The interest rate rises by a certain amount when inflation increases above its target and the interest rate falls by a certain amount when the economy goes into a recession. Fourth, to maintain its independence and focus on its main objectives of inflation control and macroeconomic stability, the Fed does not allocate credit or engage in fiscal policy by adjusting the composition of its portfolio toward or away from certain firms or sectors” (p. 4). Of course, this means we should exit from the MBS and other special programs as soon as possible. Obviously, we can't be draconian about this, but the sooner policymakers achieve this goal, the better future policy will be.

Some suggest that monetary policy has to do more things, such as taking actions to burst bubbles. Here let me say that I agree with the points made by James Bullard at the panel where these remarks were originally presented when he raised questions about whether policy can effectively pop bubbles and that it may do more harm than good. Our most successful past policy during the Great Moderation did not include such attempts to pop bubbles and the economy functioned very well. 


\section{REFERENCES}

Bernanke, Ben S. "The Great Moderation.” Remarks at the meetings of the Eastern Economic Association, Washington, DC, February 20, 2004.

Bernanke, Ben S. "Monetary Policy and the Housing Bubble." Annual Meeting of the American Economic Association, Atlanta, January 3, 2010.

Friedman, Milton and Heller, Walter. Monetary vs. Fiscal Policy: A Dialogue. New York: Norton, 1969.

Greenspan, Alan, “The Crisis.” Paper prepared for the Brookings Panel on Economics Activity, March 9, 2010.

Taylor, John B. "Housing and Monetary Policy,” in Housing, Housing Finance, and Monetary Policy, Federal Reserve Bank of Kansas City Symposium, Jackson Hole, WY, September 1, 2007.

Taylor, John B. "The Financial Crisis and the Policy Responses: An Empirical Analysis of What Went Wrong," in A Festschrift in Honour of David Dodge's Contributions to Canadian Public Policy. Ottawa: Bank of Canada, November 2008, pp. 1-18.

Taylor, John B. Getting Off Track: How Government Actions and Interventions Caused, Prolonged, and Worsened the Financial Crisis. Stanford: Hoover Press, 2009.

Taylor, John B. “The Fed and the Crisis: A Reply to Ben Bernanke.” Wall Street Journal, January 11, 2010a.

Taylor, John B. “An Exit Rule for Monetary Policy.” Testimony before the Committee on Financial Services, U.S. House of Representatives, March 25, 2010b.

Taylor, John B. and Williams, John C. “A Black Swan in the Money Market.” American Economic Journal: Macroeconomics, January 2009, 1(1), pp. 58-83. 